Received: 03.03.2017.

UDK: 81'221:159.942-055.52-055.62

Original scientific work

\title{
FACIAL EXPRESSIONS: CAN PARENTS RECOGNISE CHILDREN'S EMOTIONS
}

\author{
Lorena Lazarić \\ Juraj Dobrila University of Pula - Faculty of Educational Sciences \\ lorena.lazaric@gmail.com \\ Dijana Drandić \\ Juraj Dobrila University of Pula - Music Academy \\ dijana.drandic@ymail.com \\ Sara Tomažić \\ Juraj Dobrila University of Pula - Faculty of Educational Sciences
}

\begin{abstract}
Communication and the ability to understand emotions are key factors in everyday relationships between children and their parents. The purpose of this research is to identify whether parents are able to recognize emotions in their children's facial expressions and to explore if there is a difference between parents recognising the emotion in regard to their gender, age or the number of children they have. The sample of examinees consisted of $\mathrm{N}=273$ parents of preschool-aged children attending kindergartens. The results of the survey demonstrate that emotions which are mostly recognized by parents are: fear, anger, surprise, disgust, happiness and sadness, whereas fear proved to be the most easily recognized emotion and sadness the least easily recognized emotion. It has also been established that parents' answers do not show greater inconsistencies, and that no relevant correlation between gender, age and the number of children and the level of parents' recognition of six basic emotions through children's facial expressions has been found.
\end{abstract}

Keywords: emotional intelligence, non-verbal communication, family, preschool children, socialisation. 


\section{INTRODUCTION}

According to Le Roux (2002), nonverbal communication or communication without words can replace verbal communication through three of its important functions: social interaction, the expression of attitudes and the expression of emotional states. Understanding the importance of nonverbal communication indicates the importance of observing it as an integral part of any relationship and of perceiving one's own nonverbal behaviour as well as the "user's" behaviour, so to be able to use this information during offering effective interventions and using knowledge and social skills. Long ago have social psychologists (Allport, 1955, 1961; Myers, 1993) considered visual communication as one of the most important channels of nonverbal communication, while facial expressions through the observation of movements and face expressions was given a special significance. Researches about face expressions have revealed its role in the expression of emotions. The first to notice that face expressions caused by certain emotions are universal was Darwin in 1872 (according to Ekman, 1998). His ideas about emotions as the centre of the theory of evolution, where face expressions and emotions are innate, were later confirmed by Ekman's researches $(1970,1999)$ which proved that face expressions caused by emotions were universal for all cultures, and emphasis was put on six basic ones: anger, disgust, fear, happiness, sadness and surprise. Consequently, Ekman and Friesen (1971) have developed the FACS theory (Facial Action Coding System), i.e. the recognition of various emotional face expressions, according to which facial expression, or movements and the position of muscles which move and express certain emotional states, are a form of nonverbal communication. Namely, according to Shariff and Tracy (2011) and Mondloch (2012), face expressions in communication determine six functions of nonverbal signs: expression of emotions, expression of attitudes, demonstration of personal traits, supplementing verbal communication, replacing verbal communication and behaviour in certain social situations.

Accepting and expressing emotions and understanding children's emotional development emphasize the parents' role and their reaction to children's emotions. Children tend to express their emotions freely and thus, according to Čudina Obradović and Obradović (2006), the parents' role is to recognise these emotions, to interpret them correctly and to react to them as to make children feel safe and protected. According to Gao and Maurer (2009) by expressing emotions with face expressions children send messages to parents about situations and states they are currently in, which is important for mutual understanding and timely parents' reactions. Children can best develop their natural potentials, considers Richter (2004), interacting with parents who recognise and appropriately react to signals sent by children. For Daly (2007), according to Pećnik, Radočaj and Tokić $(2011,626)$, each parent, along with sensitivity and orientation toward the child, has six most important responsibilities toward the child: fulfilment of the child's basic physical needs; care for the child's safety inside and out of the home; giving emotional warmth; giving stimulating conditions for learning and development; directing and placing boundaries and providing stability for the child's physical environment and social relations. Appreciation of the child as a person and respect for its individuality 
is connected to the child's need and right to be seen, heard and respected as a person who expresses one's feelings, thinks Radočaj (2008). For Widen and Russel (2012, 2010a, 2010b), children learn to identify their emotions at an early age and often react adequately in certain emotional situations. Along with basic emotions which appear after the third year of age, children are aware of their emotional behaviour and start to talk about their emotions and transfer it to the environment that surrounds them. In the continuation of their growing-up period they keep learning and developing more complex emotions (proud, guilt, shame) and show them by facial expressions (Brajša - Žganec, 2003; Widen and Russel 2008). For the child's overall development, it is thus necessary, as determined by Miljković and Rijavec (2012), for parents to notice, recognise and confirm children's personal experience and to encourage them to express both pleasant (happiness) and unpleasant (sadness) emotions. Communication between parents and the child, through understanding and recognising emotions, encourages, according to Chronaki et al. (2015), children's social and emotional competencies. It is therefore important to encourage and develop the mutual emotional interaction for parents to be able to recognise and understand how children feel through their facial expression. Such expression of emotions relates to the reflexive constitution of a certain face expression which is different for each single emotion. The capability of parents to recognise and understand what children feel is connected to the awareness of their own emotions, socialization experiences, as well as the emotional reaction to the child's state. Regardless of the way children show their emotions or reactions, it is important, as claimed by Widen and Russel (2011) and Gao and Maurer (2009), for parents to recognise emotions the child is experiencing on time.

\section{METHOD}

\section{Examinees}

The sample of examinees consisted of 273 parents of preschool-aged children attending kindergartens of the County of Istria. There were 209 (76.6\%) women and 64 (23.4\%) men participating in the survey. Regarding the examinees' age, there were 27 (42.2\%) men, mostly between the age of 40 and 50, while there were 91 (43.5\%) women, mostly between the age of 30 and 40 (Table 1.). 
Table 1. Examinees according to age and sex (frequency and percentage), $N=273$

\begin{tabular}{|l|c|c|c|c|c|c|}
\hline \multirow{2}{*}{ age } & \multicolumn{2}{c|}{ men } & \multicolumn{2}{c|}{ women } & \multicolumn{2}{c|}{ total } \\
\cline { 2 - 7 } & $f$ & $\%$ & $f$ & $\%$ & $f$ & $\%$ \\
\hline Less than 20 & 0 & 0.0 & 2 & 1.0 & 2 & 0.7 \\
\hline From 20 to 30 & 8 & 12.5 & 37 & 17.7 & 45 & 16.5 \\
\hline From 30 to 40 & 20 & 31.3 & 91 & 43.5 & 111 & 40.7 \\
\hline From 40 to 50 & 27 & 42.2 & 67 & 32.1 & 94 & 34.4 \\
\hline More than 50 & 9 & 14.1 & 12 & 5.7 & 21 & 7.7 \\
\hline$N$ & 64 & 100.00 & 209 & 100.00 & 273 & 100.00 \\
\hline
\end{tabular}

The average number of children parents have is $M=2.53$. In Table 2. it can be seen that the largest number of parents, of both male 25 (39.1\%) and female 87 (41.6\%) sex, usually have two children, while only $45(16.5 \%)$ of parents of both sexes have four or more children.

Table 2. Examinees according to the number of children (frequency and percentage), $\mathrm{N}=273$

\begin{tabular}{|l|c|c|c|c|c|c|}
\hline No. of children & \multicolumn{2}{|c|}{ men } & \multicolumn{2}{c|}{ women } & \multicolumn{2}{c|}{ total } \\
\hline & $f$ & $\%$ & $f$ & $\%$ & $f$ & $\%$ \\
\hline One child & 10 & 15.6 & 47 & 22.5 & 57 & 20.9 \\
\hline Two children & 25 & 39.1 & 87 & 41.6 & 112 & 41.0 \\
\hline Three children & 16 & 25.0 & 43 & 20.6 & 59 & 21.6 \\
\hline $\begin{array}{l}\text { Four and more } \\
\text { children }\end{array}$ & 13 & 20.4 & 32 & 15.3 & 45 & 16.5 \\
\hline $\boldsymbol{N}$ & 64 & 100.00 & 209 & 100.00 & 273 & 100.00 \\
\hline
\end{tabular}

\section{Instrument}

Data has been collected by an anonymous questionnaire "Parents' Questionnaire - How Do I Recognise Emotions?” The questionnaire consisted of nine closed-ended, multiple choice questions. The first three questions were about the examinees' personal information (sex, age and the number of children they have), while the remaining six questions were about recognising the six basic emotions. For the needs of the questionnaire, photographs of children's faces were retrieved from the board game called Emotions Game of a Spanish toy manufacturer (Akros - Interdidak S.l. Valencia, España). The pictures shown to the parents represented six photographs of the same child, but with different face expressions. The characteristic face expressions with the six 
basic emotions were chosen for this occasion: happiness, sadness, anger, fear, disgust and surprise. Photographs of the same child were chosen because various researches showed that in the interpretation of emotions photographs of face expressions were more realistic and more easily recognisable than drawings.

\section{Procedure}

Parents, participators of the research, had to recognise the six different face expressions (happiness, sadness, anger, fear, disgust and surprise) after each presented picture and after they identified the face expression, they had to circle the letter before the answer which, in their opinion, represented a certain emotion. Five answers were offered to each question which regarded the identification of an emotion. The tests were individually applied and the participators were instructed to look carefully at the photographs and determine which emotion was expressed on the child's face. The following value parameters were chosen to evaluate the interpretation of emotions through facial expressions:

$$
\begin{aligned}
& \text { From } 89-100 \% \text { - excellent interpretation } \\
& \text { From } 76-88 \% \text { - very good interpretation } \\
& \text { From } 63-75 \% \text { - good interpretation } \\
& \text { From } 50-62 \% \text { - satisfactory interpretation } \\
& \text { From } 0-49 \% \text { - unsatisfactory interpretation }
\end{aligned}
$$

Data was processed by the application of the SPSS package and by calculating the descriptive statistic, a central tendency was determined and expressed in percentages. To determine if there are statistically significant differences in the parents' recognition of the six basic emotions regarding sex, age or the number of children, the chi-square tests and one-way analyses of variance were conducted. The existence of correlations, i.e. the mutual correlation between the parents' answers and their characteristics, was also checked.

\section{Problems and hypotheses}

Communication and understanding emotions between parents and children is important in their everyday relationship. According to Brajša - Žganec and Slunjski (2007), parents should be able to decode their children's emotional expressions and understand how the child feels based on his or her facial expression. Therefore, the mere awareness of children's emotional development emphasizes the role of parents' reactions to their emotions.

The aim of this research is to determine if parents recognise children's emotional expressions and if there are differences among parents in recognising the emotions regarding their sex, age and the number of children they have. 
Hypotheses:

$\mathrm{H} 1$ - it is assumed that the most precisely recognised emotion by parents is children's fear $\mathrm{H} 2$ - it is assumed that the worst recognised emotion by parents is children's sadness $\mathrm{H} 3$ - the difference in the recognition of children's emotions was not noticed in regard to the parents' sex

\section{RESULTS AND DISCUSSION}

To determine the extent to which parents are able to recognise children's emotional expressions, Table 3. was used to show the frequency and percentage of parents who correctly recognised each of the 6 basic emotions: fear, anger, surprise, disgust, happiness and sadness, as well as the wrongly recognised emotions in the parents' answers. To recognise emotions upon face expressions, five different answers were offered, but only one was correct and it regarded the recognition of a certain emotion according to the face expression of the child on the photograph. Observers, in this case parents, were looking for different emotions on different parts of the face. According to Ekman (1999), surprise is displayed on the forehead, in the eyes and movements of the lips, while anger is shown on the whole face. According to Brajša - Žganec (2003), fear is more common in children from the seventh year of age on, and it occurs due to an experienced unpleasant situation, but also by imitating adults. Fear can be clearly seen in the startled expression in the eyes. Parents recognised the emotion of fear in the high percentage of $89 \%$. However, according to the facial expression, $11 \%$ of parents did not recognise the emotion of fear correctly, but they recognised some other emotions: impertinence (4.4\%) and arrogance $(4.4 \%)$, while some of them noticed that the child's expression showed happiness $(1.5 \%)$ or even shame $(0.7 \%)$.

Table 3. The frequency and percentage of parents who recognised emotions $(\mathrm{N}=273)$

\begin{tabular}{|c|c|c|c|}
\hline emotions & recognition & $\boldsymbol{f}$ & \% \\
\hline \multirow{3}{*}{ fear } & impertinence & 12 & 4.4 \\
\cline { 2 - 4 } & arrogance & 12 & 4.4 \\
\cline { 2 - 4 } & happiness & 4 & 1.5 \\
\cline { 2 - 4 } & shame & 2 & 0.7 \\
\cline { 2 - 4 } & fear & 243 & 89.0 \\
\hline \multirow{4}{*}{ anger } & Surprise & 10 & 3.7 \\
\cline { 2 - 4 } & disappointment & 6 & 2.2 \\
\cline { 2 - 4 } & anger & 203 & 74.4 \\
\cline { 2 - 4 } & distrust & 52 & 19.0 \\
\cline { 2 - 4 } & worry & 2 & 0.7 \\
\cline { 2 - 4 } & & & \\
\hline
\end{tabular}




\begin{tabular}{|c|c|c|c|}
\hline \multirow[t]{5}{*}{ surprise } & confusion & 4 & 1.5 \\
\hline & surprise & 231 & 84.6 \\
\hline & curiosity & 4 & 1.5 \\
\hline & boldness & 16 & 5.9 \\
\hline & interest & 18 & 6.6 \\
\hline \multirow[t]{5}{*}{ disgust } & disgust & 219 & 80.2 \\
\hline & doubt & 34 & 12.5 \\
\hline & anger & 5 & 1.8 \\
\hline & impatience & 5 & 1.8 \\
\hline & boredom & 10 & 3.7 \\
\hline \multirow[t]{5}{*}{ happiness } & happiness & 205 & 75.1 \\
\hline & safety & 13 & 4.8 \\
\hline & interest & 11 & 4.0 \\
\hline & surprise & 33 & 12.1 \\
\hline & honesty & 11 & 4.0 \\
\hline \multirow[t]{5}{*}{ sadness } & confusion & 26 & 9.5 \\
\hline & sadness & 176 & 64.5 \\
\hline & worry & 24 & 8.8 \\
\hline & shame & 5 & 1.8 \\
\hline & disappointment & 42 & 15.4 \\
\hline
\end{tabular}

As described by Givens (2002), signs of anger include stiffness of the body, frowned eyebrows, stiffened mouth, widened nostrils and "lightning coming out of the eyes." Anger is clearly displayed in the lower part of the face and in the eyebrow region. Anger was correctly recognised by $74.4 \%$ of parents. However, even $19 \%$ of parents recognised distrust instead of anger. Surprise is an emotion which is said to appear in situations when something unexpected occurs. A surprised face expression is characterised by an open mouth, widely open eyes and it was correctly recognised by $84.6 \%$ of parents. Ekman (1998) thinks that disgust is an emotion pushing us to throw up and which is very disturbing. Thus, the face expression for this emotion is extremely distorted and unnatural. In this research, disgust was correctly recognised by $80.2 \%$ of parents, while $12.5 \%$ of parents replaced the emotion of disgust with doubt. Most authors (Ekman, 1999; Givens, 2002) are of the opinion that the emotion of happiness is the easiest to recognise because it is connected to enjoyment, pleasure, friendship and positive emotions which can be see "in our eyes." Therefore, happiness is a universal and easily recognisable emotion depicted by a sincere smile with ends of the lips and eyes lifted up so that "the whole face is a big smile." Happiness was correctly recognised by $75.1 \%$ of parents, while $12.1 \%$ of them thought that the offered face expression was a characteristic of surprise, 
not happiness. The feeling of happiness is connected to joy from the children's early ages and it occurs in a pleasant external situation, a joyful and encouraging environment. Further on, the emotion of sadness represents the shape of a face crying. Although tears represent sad states, they can sometimes be noticed with the emotion of happiness and as such they are not a reliable indicator of sadness. Only $64.5 \%$ of parents recognised the emotion of sadness correctly, while $15.4 \%$ of them thought that that the displayed face expression was the one of disappointment.

In the interpretation of emotions through facial expressions, the correctness of answers can be ranked according to the given parameters of value. The emotion of fear had $89 \%$ of exact recognitions and the emotion of surprise had $84.6 \%$ so they can be ranked into excellent interpretation. The emotion of disgust had $80.2 \%$ of recognition and a very good parents' interpretation. The next two emotions, anger with $74.4 \%$ and happiness with $75.1 \%$, were well recognised by parents, while the emotion of sadness with its $64.5 \%$ was the worst recognised one, although it can be put in the category of good interpretations of emotional expressions of the face.

In Table 4. it can be noticed that all the six emotions were better recognised by women than by men. If the results are analysed according to age, all parents who were younger than 20 recognised the emotions of fear, anger, surprise, disgust and happiness, while only half of them (50\%) recognised sadness. Although there are studies (Fox, 2001; Thomas et al., 2007) claiming that the capability of recognising emotions on the face improves with age, this research has shown that only the emotion of sadness was recognised by more parents older than 20 (59.1\%), older than 30 (61.3\%), older than 40 (70.2\%) and older than $50(71.4 \%)$ than by those younger than 20 . Parents who have one child were more correct in recognising fear (94.7\%), anger (80.7\%) and disgust (86.0\%) on their children's faces than those who had a larger number of children. The emotion of happiness $(80.0 \%)$ and sadness $(77.8 \%)$ was correctly recognised by parents who had four and more children. The noticed differences between parents in recognising children's emotions indicate that parents are still maturing and constantly learning how to improve and/or correctly "read" a non-verbal communication message. This research results have also shown a high correctness in the estimation of primary emotions regarding sex, age or the number of children. Parents' emotional intelligence thus includes the ability to precisely notice and recognise the expression of emotions with children. The children's constant need for love, emotional care, acceptance, connection and safety demands, as considered by Pećnik (2008), the parents' sensitivity to messages and an adequate reaction to them, the expression of warmth and love, acceptance and support. 
Table 4. Percentage according to characteristics of parents who correctly recognised emotions

\begin{tabular}{|c|c|c|c|c|c|c|c|c|c|c|c|}
\hline \multirow{2}{*}{ emocije } & \multicolumn{10}{|c|}{ ispitanici prema karakteristikama } \\
\cline { 2 - 13 } & \multicolumn{3}{|c|}{ sex \% } & \multicolumn{8}{c|}{ age \% } \\
\cline { 2 - 13 } & male & female & $<20$ & $\begin{array}{c}20- \\
30\end{array}$ & $\begin{array}{c}30- \\
40\end{array}$ & $\begin{array}{c}40- \\
50\end{array}$ & $>50$ & one & two & three & $>$ four \\
\hline fear & 84.4 & 90.4 & 100 & 90.9 & 87.5 & 87.2 & 100 & 94.7 & 84.7 & 89.3 & 86.7 \\
\hline anger & 73.4 & 74.6 & 100 & 70.5 & 77.5 & 73.5 & 66.7 & 80.7 & 72.9 & 73.2 & 71.1 \\
\hline surprise & 82.8 & 85.2 & 100 & 88.6 & 75.0 & 86.2 & 81.0 & 80.7 & 84.7 & 90.2 & 75.6 \\
\hline disgust & 78.1 & 80.9 & 100 & 79.5 & 79.5 & 80.9 & 81.0 & 86.0 & 78.0 & 83.0 & 68.9 \\
\hline happiness & 71.9 & 76.1 & 100 & 65.9 & 76.8 & 76.6 & 76.2 & 78.9 & 72.9 & 72.3 & 80.0 \\
\hline sadness & 62.5 & 65.1 & 50.0 & 59.1 & 61.3 & 70.2 & 71.4 & 59.3 & 68.8 & 66.7 & 77.8 \\
\hline
\end{tabular}

To assess the existence of statistically significant differences in the parents' recognition of basic emotions according to their sex, age and the number of children, the chi-square test regarding the parents' characteristics was conducted and the correlation coefficients were calculated (Table 5.). The chi-square test has determined that, regarding each emotion which had to be recognised, the parent's answers were not significantly different except for the emotions of disgust and sadness. It has been determined that the result $\chi^{2}=25.388 ; \mathrm{df}=12 ; \mathrm{C}=.305$ for the emotion disgust suggests that the parents' answers differed regarding the number of children they had, because a somewhat smaller number of parents having three children succeeded to correctly recognise the emotion of disgust in comparison to other parents. However, regarding the level of significance, it can be determined that the recognition of the emotion disgust does not significantly differ in the parents' answers regarding the number of children, nor is this fact connected to the correct recognition of the aforementioned emotion. It has also been determined that the parents' answers according to the number of children and regarding the emotion of sadness do not significantly differ, because the chi-square test showed $\chi^{2}=23.958 ; \mathrm{df}=12$; $\mathrm{C}=.197$, namely that the differences found in the answers were not statistically significant and that a connection between recognising the emotion and the number of children parents had was not noticed. The results obtained for all the studied emotions suggest the following: parents of the male or female sex, aged 20,30,40, 50 or older than 50, who have one, two, three or four and more children recognise the emotions of fear, anger, surprise, disgust, happiness and sadness equally. Therefore, there are no statistically significant differences in the recognition of basic emotions in regard to parents' characteristics. The obtained contingency coefficients have not shown a significant correlation between groups of parents, regardless their sex, age or number of children, in connection to the correctness in recognising the six basic emotions presented in this research. In other words, the correlation of sex, age and the number of children with the parents' ability to correctly recognise the emotion of fear, anger, surprise, disgust, happiness and sadness in 
children's facial expressions has not been determined.

The ability to recognise and interpret emotional signs enables parents to predict events and to react to them in a proper way. Children react to their environment's stimuli in a spontaneous and emotional way and it is therefore important for their general psychical development to enable their interaction and communication with the environment they grow up in, and in this sense, the parents' role is crucial. In all growing-up periods, the child's emotional development is important for the formation of personality, especially in regard to the feeling of safety and understanding given by parents.

Table 5. The chi-square test results according to the type of emotion and the parents' characteristics

\begin{tabular}{|c|c|c|c|c|c|c|c|c|c|}
\hline emotions & \multicolumn{3}{|c|}{ sex } & \multicolumn{3}{c|}{ age } & \multicolumn{3}{c|}{ no. of cildren } \\
\hline & $\chi^{2}$ & $d f$ & $C$ & $\chi^{2}$ & $d f$ & $C$ & $\chi^{2}$ & $d f$ & $C$ \\
\hline fear & 3.230 & 4 & .109 & 9.96 & 16 & .186 & 11.817 & 12 & .208 \\
\hline anger & 1.514 & 4 & .074 & 6.148 & 16 & .150 & 10.301 & 12 & .194 \\
\hline surprise & 4.006 & 4 & .121 & 15.355 & 16 & .237 & 14.494 & 12 & .230 \\
\hline disgust & 5.966 & 4 & .148 & 20.131 & 16 & .272 & 25.388 & 12 & .305 \\
\hline happiness & 2.358 & 4 & .093 & 20.131 & 16 & .212 & 10.357 & 12 & .195 \\
\hline sadness & 1.488 & 4 & .143 & 23.958 & 16 & .132 & 23.958 & 12 & .197 \\
\hline
\end{tabular}

legend: $\chi^{2}=$ chi-square test; $\mathrm{df}=$ degrees of freedom; $\mathrm{C}=$ contingency coefficient

\section{CONCLUSION}

The aim of this study was to determine the parents' ability to recognise the children's expressed emotion by accurately observing their facial expression. The results of the conducted research show that parents mostly recognise the children's emotions of fear, anger, surprise, disgust, happiness and sadness, where the emotion of fear is the best recognised, and the emotion of sadness the worst recognised one. Hypothesis 1 , which says that the most precisely recognised emotion by parents is children's fear, can be accepted. It was noticed that parents rarely mixed the emotion of fear with some other emotion, i.e. they most often recognised it in the children's stunned expression of the eyes. Hypothesis 2 , which says that the worst recognised emotion by parents is children's sadness, can be accepted. It was studied and determined that parents, according to the children's whining faces, sometimes mixed the emotion of sadness with the emotion of disappointment. Hypothesis 3, which says that the difference in the recognition of children's emotions was not noticed in regard to the parents' sex, can be accepted. It was proved that all six emotions were better recognised by women than men. It is also necessary to emphasize that women, younger parents and parents with one child were better at interpreting almost all facial expressions. It should be pointed out that the differences in the interpretation 
between parents in regard to their characteristics (sex, age and number of children), are not statistically significant for this research. The face represents the most important channel of non-verbal communication, face expressions are used in a wide spectrum of social situations, especially when one' own emotions, personality traits, intelligence, temperament and similar things want to be shown. Therefore, facial expressions are the constituent part of emotions and the means for identification of types of emotions.

This paper is about basic emotions and the facial expressions revealing them. The identification and understanding of children's emotions is useful to encourage children's social and emotional competencies, as well as the children's need and right to be seen and heard. The intention of this study was to find out if parents were able to observe, recognise and accept the non-verbally expressed children's needs, make them think and encourage them to train "two-way" communication and to actively "listen" to children from their point of view, to give sense to communication (especially to the non-verbal one) and, in the end, to lead parents to be open for any type of communication since to notice sometimes means to open one's way to the child's heart. This implies spending more time and paying attention, showing interest for children's everyday activities and recognising children's wishes. It is necessary for the parent to listen to their children and help them to express their thoughts and feelings. Furthermore, this paper represents an incentive for future researches of emotions with children of different ages, as well as for researches about the influence of parents' emotional competencies on the overall development of the child.

\section{REFERENCES}

1. Allport, G. W. (1961). Pattern and growth in personality. Oxford, England: Holt, Reinhart \&Winston.

2. Allport, G.W. (1955). Becoming: Basic considerations for a psychology of personality. New Haven: Yale University Press.

3. Brajša-Žganec, A. (2003). Dijete i obitelj: emocionalni i socijalni razvoj. Jastrebarsko: Naklada Slap.

4. Brajša-Žganec, A., Slunjski, E. (2007). Socioemocionalni razvoj u predškolskoj dobi: povezanost razumijevanja emocija i prosocijalnog ponašanja. Društvena istraživanja. 16 (3), 477-496.

5. Chronaki,G., Hadwin,A.J., Garner, M., Maurage, P., Sonuga-Barke, E.(2015). The development of emotion recognition from facial expressions and non-linguistic vocalizations during childhood. British Journal of Developmental Psychology, 33(2), 218-236.

6. Čudina-Obradović, M., Obradović, J. (2006). Psihologija braka i obitelji, Zagreb: Golden marketing.

7. Daly, M. (2007). Parenting in Contemporary Europe: A Positive Approach, Strasbourg, Council of Europe Publishing.

8. Ekman, P. (1999). Emotional And Conversational Nonverbal Signals. In L.Messing \& 
R. Campbell (eds.) Gesture, Speech and Sign. pp. 45-55. London: Oxford University Press.

9. Ekman,

P.

(1998).

Universality

Of

Expression?

A personal

History of

The

Emotional

In Ekman, P. (ed) Third edition of Charles Darwin's the Expression of the Emotions in Man and Animals, with introduction, afterwords, and commentaries (363-393). London: HarperCollins.

10. Ekman, P. (1970). Universal facial expressions of emotion, California Mental Health Research Digest.

11. Ekman, P., Friesen, W.V. (1971). Constants across cultures in the face and emotion. Jurnal of Personality and Social Psychology, 17 (2), 124-129.

12. Fox, J. (2001). Identifying emotions in faces: A developmental study. Washington, DC: Intel Science Talent Search.

13. Givens, D. (2002). The Nonverbal Dictionary of gestures, signs and body language cues. Washington: Center for nonverbal studies press.

14. Gao, X., Maurer, D. (2009). Inuence of intensity on children's sensitivity to happy, sad, and fearful facial expressions. Journal of Experimental Child Psychology, 102(4), 503-521.

15. Le Roux, J. (2002). Effective educators are culturally competent communicators. Intercultural Education, 13(1), 37-48.

16. Mondloch C. J. (2012). Sad or fearful? The influence of body posture on adults' and children's perception of facial displays of emotion. Journal of Experimental Child Psychology,111, 180-196.

17. Miljković, D., Rijavec, M. (2012). Bolje biti vetar nego list - psihologija dečjeg samopoudanja (treće izdanje), Čačak: Legenda.

18. Myers, D.G. (1993). Social Psychology. McGraw Hill, Inc.

19. Pećnik, N., Radočaj, T., Tokić, A. (2011). Uvjerenja javnosti o ispravnim roditeljskim postupcima prema djeci najmlađe dobi. Društvena istraživanja 20 (3), 625-646.

20. Pećnik, N. (2008). Suvremeni pogled na dijete, roditeljstvo i socijalizaciju. Dijete i društvo,10(2/1), 99-115.

21. Radočaj, T. (2008). Što (ne) znaju i što čine roditelji najmlađe djece? Dijete i društvo, $10(1 / 2), 119-135$.

22. Richter, L. (2004.). The Importance of Caregiver-Child Interactions for the Survival and Healthy Development of Young Children. A Review. Geneva: World Health Organisation.

23. Shariff A. F., Tracy J. L. (2011). What are emotion expressions for? Current Directions in Psychological Science, 20, 395-399.

24. Thomas, L. A., De Bellis, M. D., Graham, R., LaBar, K. S. (2007). Development of emotional facial recognition in late childhood and adolescence. Developmental Science, 10(5), 547-558.

25. Widen, S. C., Russell, J. A. (2008). Children acquire emotion categories gradually. Cognitive Development, 23, 291-312.

26. Widen S. C., Russell J. A. (2010a). Differentiation in preschooler's categories for 
emotion. Emotion, 10, 651-661. doi: 10.1037/a0019005.

27. Widen S. C., Russell J. A. (2010b). Children's scripts for social emotions: Causes and consequences are more central than are facial expressions. British Journal of Developmental Psychology, 28, 565-581. doi: 10.1348/026151009X457550d.

28. Widen S. C., Russell J. A. (2011). In building a script for an emotion, do preschoolers add its cause before its behavior consequence? Social Development, 20, 471-485. doi: 10.1111/j.1467-9507.2010.00594.x.

29. Widen S. C., Russell J. A. (2012). Children's recognition of disgust in others. Psychological Bulletin, 139(2), 271-299. 